\title{
Dietary Protein and Muscle in Aging People: The Potential Role of the Gut Microbiome
}

\author{
Mary Ni Lochlainn ${ }^{1,2, *(1)}$, Ruth C. E. Bowyer ${ }^{1}$ and Claire J. Steves ${ }^{1,2}$ (i) \\ 1 The Department of Twin Research, Kings College London, 3-4th Floor South Wing Block D, \\ St Thomas' Hospital, Westminster Bridge Road, London SE1 7EH, UK; ruth.c.bowyer@kcl.ac.uk (R.C.E.B.); \\ claire.j.steves@kcl.ac.uk (C.J.S.) \\ 2 Clinical Age Research Unit, Kings College Hospital Foundation Trust, London SE5 9RS, UK \\ * Correspondence: marynilochlainn@gmail.com
}

Received: 8 June 2018; Accepted: 18 July 2018; Published: 20 July 2018

check for updates

\begin{abstract}
Muscle mass, strength, and physical function are known to decline with age. This is associated with the development of geriatric syndromes including sarcopenia and frailty. Dietary protein is essential for skeletal muscle function. Resistance exercise appears to be the most beneficial form of physical activity for preserving skeletal muscle and a synergistic effect has been noted when this is combined with dietary protein. However, older adults have shown evidence of anabolic resistance, where greater amounts of protein are required to stimulate muscle protein synthesis, and response is variable. Thus, the recommended daily amount of protein is greater for older people. The aetiologies and mechanisms responsible for anabolic resistance are not fully understood. The gut microbiota is implicated in many of the postulated mechanisms for anabolic resistance, either directly or indirectly. The gut microbiota change with age, and are influenced by dietary protein. Research also implies a role for the gut microbiome in skeletal muscle function. This leads to the hypothesis that the gut microbiome might modulate individual response to protein in the diet. We summarise the existing evidence for the role of the gut microbiota in anabolic resistance and skeletal muscle in aging people, and introduce the metabolome as a tool to probe this relationship in the future.
\end{abstract}

Keywords: protein; skeletal muscle; sarcopenia; gut microbiome; metabolome; diet; supplementation

\section{Introduction}

Skeletal muscle has several important functions beyond locomotion, including insulin-stimulated glucose uptake, influence on bone density via mechanical force on bones, and whole-body protein metabolism [1]. Age associated loss of muscle mass starts as early as age thirty, and is a gradual process [1]. Older people lose more skeletal muscle with bedrest and show an attenuated response to retraining after immobilisation, in comparison to younger individuals [2-4]. Sarcopenia is a geriatric syndrome defined as the age-related loss of skeletal mass and function, quantified by objective measures of muscle mass, strength, and physical function [5]. One major risk factor for the development of sarcopenia is protein-energy malnutrition [6]. A number of factors can lead to reduced protein intake in older age, as summarised in Figure 1 [7-18]. Patients with sarcopenia are often frail (vulnerable to minor stressors) and the two concepts (frailty and sarcopenia) share an increased risk of adverse outcomes [19]. As life expectancy worldwide has more than doubled over the past two centuries, the importance of understanding and optimising muscle function in older age is paramount. 


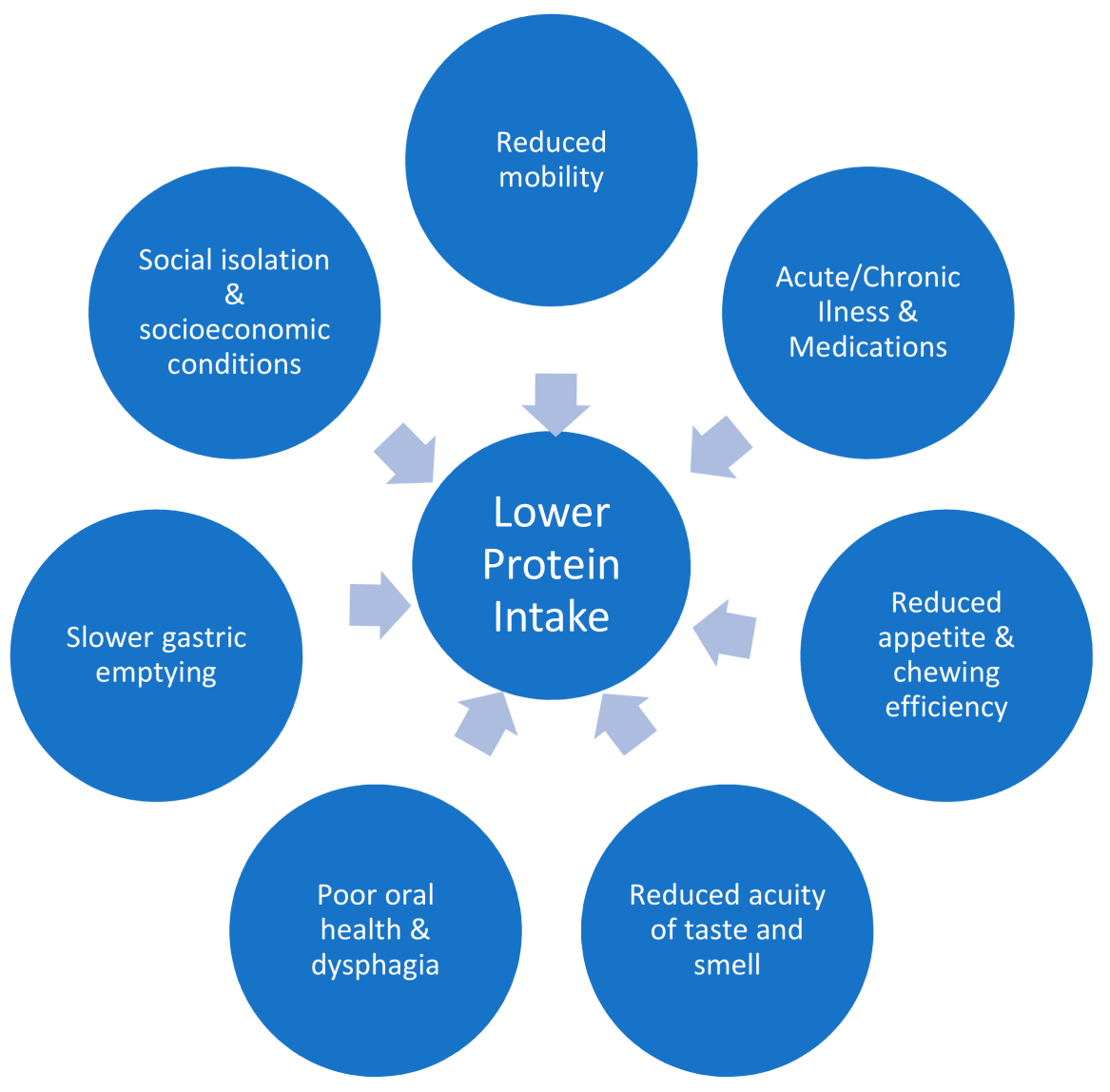

Figure 1. Factors leading to lower protein intake in older adults.

Three large observational studies have supported an association between protein intake and muscle strength and mass [20-22], but multiple trials carried out in healthy, replete, older adults, without an exercise intervention, have been negative [23-25]. In those with suboptimal protein intake, the most promising results are for specific essential amino acids, particularly leucine, but also its metabolite $\beta$-hydroxy $\beta$-methylbutyric acid (HMB) [25-29]. Supplementation with these more targeted regulators of muscle protein synthesis (MPS) may be most effective for overcoming anabolic resistance in this cohort, especially if combined with exercise, a potent stimulator of anabolic response in muscle at all ages [28,30-32]. Anabolic resistance refers to the phenomenon whereby older adults require a higher dose of protein to achieve the same response in MPS as a younger adult [1]. The aetiologies and mechanisms for this are not understood, but we propose that the gut microbiome may be implicated in one or many of those suggested in the literature.

The gut microbiome is composed of bacteria, archaea, viruses, and eukaryotic microbes that reside in the gut. Its role in maintaining a healthy physiology and contributing to disease is a rapidly evolving field of enquiry. The gut microbiome has a collective genome size that may be as much as 150 -fold that of the human host [33], and it has been argued that the metabolic capacity of microbiota merits its consideration as an organ of the human body in its own right, with its own intrinsic functions and metabolic needs [34]. With age and frailty in particular, the resilience of the gut microbiome is reduced, as it becomes more vulnerable to medications, disease, and changes in lifestyle, with changed species richness and increased inter-individual variability [35-37]. The potential of the gut microbiota to alter physiology has been shown by landmark animal studies assessing faecal transplant, which have demonstrated body composition changes in the recipient reflective of the phenotype of the donor [38]. This highlights the role of microbiota in characterising metabolic phenotypes, which we are only now beginning to understand. 
Ageing is associated with chronic inflammation [39], often referred to as 'inflammaging'. Here we suggest that this 'inflammaging', in combination with altered gut microbiome composition and/or diversity [40], leads to changes in protein metabolism, absorption and availability; ultimately contributing to anabolic resistance and therefore to reduced MPS and the development of sarcopenia. Proposed interventions such as protein supplementation, probiotics or faecal transplants should address this rationale. This review summarises the available literature on anabolic resistance in older adults, with a particular focus on the role of the gut microbiome and its metabolome.

\section{Anabolic Resistance}

Skeletal muscle mass is regulated by the processes of muscle protein synthesis and breakdown (MPS and MPB). MPS rates are largely controlled by responsiveness to anabolic stimuli, such as consumption of food, and physical activity. Catabolic stressors include illness, physical inactivity, and inflammation, of which the older population tend to have higher rates (Figure 2). Ageing does not seem to influence MPB to the same degree as MPS, and so much of the focus of the aging literature is on MPS [27,41-43]. Older adults have shown evidence of 'anabolic resistance', whereby a higher dose of protein is required to achieve the same MPS response as a younger person $[1,28,39,40,44]$. While this concept has been questioned, especially in the context of healthy older adults [45], it is now considered consensus that a higher recommended daily amount of $1-1.3 \mathrm{~g} / \mathrm{kg} /$ day should be consumed by older people to offset catabolic conditions [1,46-49]. In the context of illness or injury, older adults may require as much as $2 \mathrm{~g} / \mathrm{kg} /$ day, as recommended by the PROT-AGE Study Group [50].

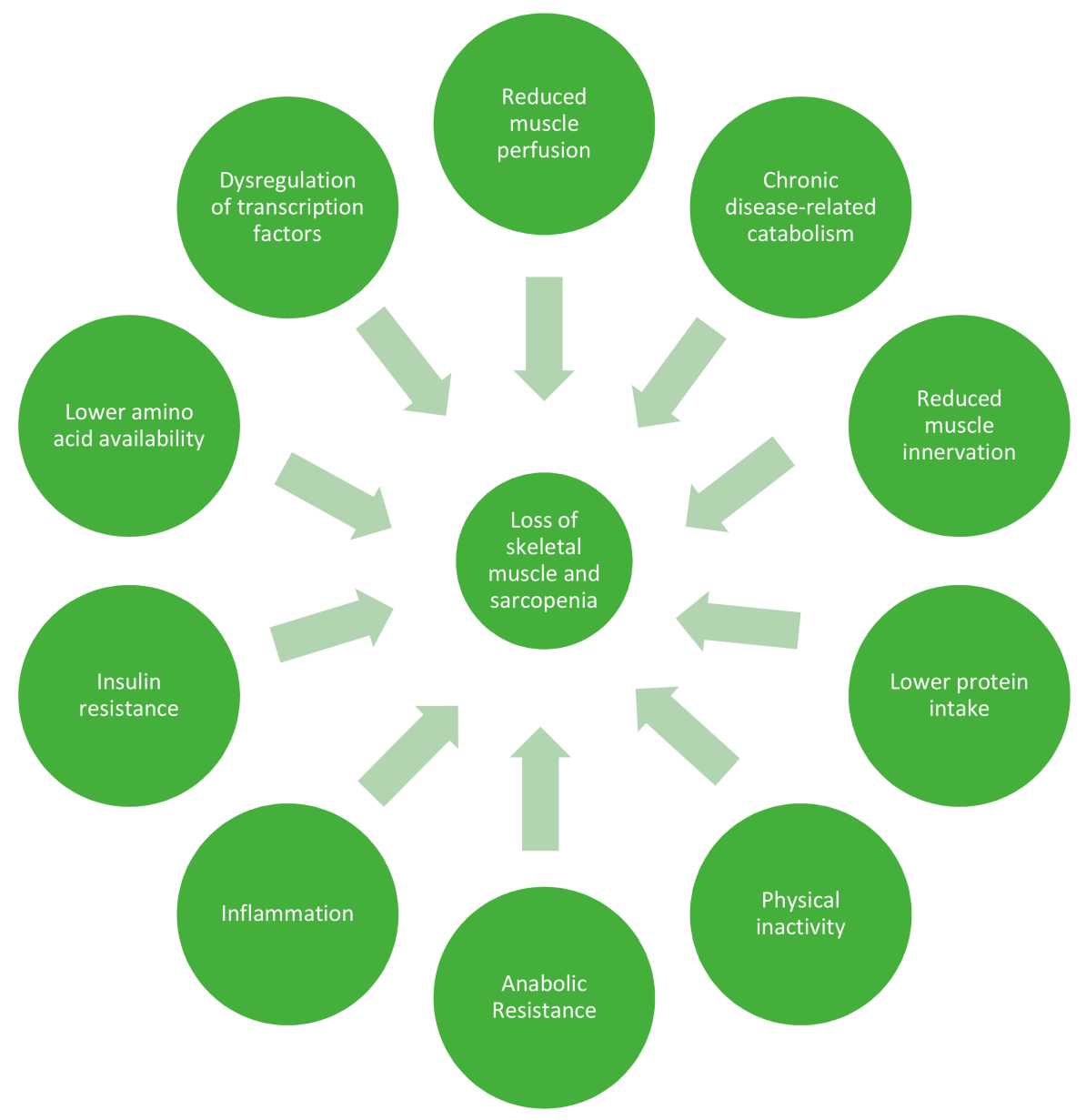

Figure 2. Factors leading to loss of skeletal muscle and sarcopenia in older adults. 
The aetiology of anabolic resistance is complex, involving aging physiology, accumulation of chronic disease, and changes in physical inactivity (see Table 1). The multiple mechanisms postulated involve impairments at most levels of protein metabolism (see Table 2). There may also be sex-differences in anabolic resistance [51-54], which has received little attention in the literature.

Table 1. Factors influencing anabolic resistance.

\begin{tabular}{cc}
\hline Anabolic Resistance Aetiology & References \\
\hline Declining activity levels & {$[1,6,55-57]$} \\
Protracted disuse events & {$[6,58-61]$} \\
Chronic inflammation & {$[31,41,56,62,63]$} \\
Insulin resistance & {$[1,27,41,62,64,65]$} \\
Higher circulating oxidative and inflammatory stressors & {$[1,27,56]$} \\
Obesity & {$[62,66]$} \\
Reduced oestrogen/testosterone & {$[1,67]$} \\
Increased production of catabolic hormones such as cortisol & {$[27]$} \\
Alcohol & {$[68]$} \\
Smoking & {$[1]$} \\
Poor vitamin D status & {$[56]$} \\
Reduced food intake & {$[56]$} \\
Metabolic acidosis & {$[1]$} \\
More chronic \& acute disease in older adults (increased catabolic conditions) & {$[50]$} \\
\hline
\end{tabular}

Table 2. Molecular mechanisms implicated in anabolic resistance.

\begin{tabular}{cc}
\hline Anabolic Resistance Mechanisms & References \\
\hline Differences in gene expression of proteins involved in MPS & {$[69-73]$} \\
Dysregulation of key signalling proteins in the mTOR pathway & {$[1,41,70,71,74,75]$} \\
Decreased phosphorylation of mTORC1 & {$[41,74,76-79]$} \\
Impaired transport of amino acids into muscle/peripheral tissues & {$[56,75,80,81]$} \\
Diminished mRNA translational signalling & {$[74,78,82,83]$} \\
Inflammation (raised TNF $\alpha /$ IL-6/hs-CRP/NFkB) & {$[1,41,74,84,85]$} \\
Decreased phosphorylation of transcription factors (e.g., p70S6K, S6K1) & {$[41,74,75,82]$} \\
Dysregulation of nutritive blood flow to skeletal muscle & {$[56,65,86]$} \\
Attenuated protein digestion \& absorption & {$[56,87-89]$} \\
Mitochondrial dysfunction & {$[1,35,72]$} \\
Autophagy/mitophagy dysfunction & {$[1,72]$} \\
Denervation of muscle fibres & {$[56,90]$} \\
Higher splanchnic extraction of protein & {$[50,88]$} \\
Lipid-induced muscle insulin resistance & {$[35,91]$} \\
Increased AMPK $\alpha$ phosphorylation (leads to increased MPB) & {$[70]$} \\
Increased cortisol generation within muscle by 11bHSD1 & {$[92]$} \\
Loss of skeletal muscle stem cells & {$[93]$} \\
\hline
\end{tabular}

\section{The Role of the Gut Microbiome}

The composition of the human gut microbiome is dependent on, amongst other things, age, diet, health, and geographical location, with significant individual variability [94,95]. It is dynamic across the lifespan, changing rapidly between birth and early childhood, and then becoming more stable [36]. In older life, however, research shows that the propensity for compositional change accelerates once again $[36,96,97]$. Multiple cross-sectional studies have found associations between gut microbiome composition and frailty [98-100], while the ELDERMET study showed significant loss of diversity amongst people in a care-home setting versus community dwellers [95]. Among older hospitalised patients, polypharmacy has been associated with gut microbiota dysbiosis [99]. It is well established that antibiotics cause significant changes in microbiota composition [101], and older adults tend to have more frequent antibiotic therapy. 
Age-related chronic inflammation ('inflammaging'), is implicated in the development of sarcopenia [102,103]. Changes in the gut microbiota have been suggested to contribute to inflammaging [37,103-105]. A recent animal study showed that transferring gut microbes of young killifish to older ones ameliorates ageing conditions, and extends the lifespan of the older fish [106]. Notably, the transplanted older fish also displayed increased 'spontaneous exploratory behaviour' [106], essentially physical activity. Few studies to date have had the ability to delve into the operational capacity and functional readout of the gut microbiome in relation to aging, but this is likely to shed more light on possible mechanisms of the interaction between dietary intake and host utilisation of protein in skeletal muscle.

\subsection{Gut Microbiota and Skeletal Muscle}

The influence of the gut microbiome in metabolic health has been one of the primary focuses of research in this area thus far, particularly in the context of obesity and insulin resistance [107]. Studies have used faecal transplants in germ-free mice to demonstrate changes in body fat, insulin resistance and glucose tolerance [108], highlighting the key role of the microbiome in these metabolic pathways. Considering the role of skeletal muscle in glucose metabolism, animal studies have investigated the relationship between gut microbiota and skeletal muscle metabolism. For example, skeletal muscle from colonised versus germ free mice appears to have altered metabolic efficiency, with higher levels of the enzyme adenosine monophosphate (AMP)-activated protein kinase, a central regulator of metabolism at both a cellular and organismal level, found in the skeletal muscle of germ-free mice [109]. CD-14 mutant mice, who lack an endotoxin receptor on their innate immune cells, have increased levels of circulating lipopolysaccharide (LPS), and this LPS was found to induce skeletal muscle inflammation, as well as insulin resistance [36]. This is important because the healthy gut microbiome is considered to contribute to gut barrier function (Section 3.3 below), providing gut enterocytes with essential nutrition [110] and reducing LPS levels in the blood. Lastly, Yan et al. (2016) carried out a study in which gut microbiota was transferred from obese pigs to germ free mice [111]. Fibre characteristics and the metabolic profile of the skeletal muscle were replicated in the recipients [111], again implicating the gut microbiome in skeletal muscle composition and metabolism. Some of the fibre changes noted were similar to those seen in aging skeletal muscle (e.g., increased proportion of slower contracting fibres). This raises the possibility that faecal microbial transplantation could be used as a means to transmit muscle fibre characteristics between humans, perhaps even from young to old, as a means of improving skeletal muscle function.

Gut microbiota modulation in animal models has also produced preliminary supportive data for effect on skeletal muscle. This includes lower intestinal permeability and lower plasma LPS and cytokines noted in prebiotic-treated mice [112], reduced expression of muscle atrophy markers in mice models of leukaemia supplemented with a Lactobacillus species [113], and increased muscle mass and function (measured by grip strength and swim time) in healthy mice supplemented with L. plantarum [114]. These studies and others [115,116], suggest that targeting the gut microbiota may be used as a tool to modulate muscle mass.

In terms of human data, two probiotic trials have shown improvements in athletic performance amongst elite athletes. A small, four week trial of probiotic capsules in male runners reported increased run time to fatigue in the probiotic group [117], while a trial of probiotic yoghurt in teenage female endurance swimmers reported improved aerobic performance, measured by maximal oxygen consumption (VO2 max) [118]. Dietary standardisation was carried out in the male runner study, however in the swimmer study participants continued their regular diet which may have confounded results. These studies build on evidence from observational studies for an association between exercise and gut microbiota [119-124]. Clark et al. (2014) compared the gut microbial diversity of professional male athletes to healthy controls and reported significantly higher diversity amongst the athletes [125]. Furthermore, moderate exercise has been shown to increase intestinal mobility [126], which is known to affect gut microbiota $[127,128]$. These changes in gut health with exercise implicate skeletal muscle as 
a potential regulator of gut microbiota composition and suggest a bi-directional relationship between skeletal muscle and the gut microbiome.

Amongst older adults, a single randomised controlled trial has explored the effect of modulating the gut microbiota on muscle function and frailty. Here, 60 older adults received a prebiotic (F-GOS) or placebo for 13 weeks. While the study remains to be replicated, promisingly, both exhaustion and handgrip strength were significantly improved in the treatment arm [129], highlighting the potential role for the gut microbiome in future interventions. The science of pre- and probiotic use is in its infancy, as are studies of faecal transplantation, with much scope for further investigation of these therapeutic options.

\subsection{Gut Microbiota and Dietary Protein}

The digestive system consists of a complex interaction between digestive secretions, intestinal conditions, and the gut microbiome. Nutrients, especially dietary proteins, provide energy sources for the host, as well as substrates for the gut microbiota [130]. A significant proportion of undigested peptides and proteins can reach the colon, and this is increased in the context of a high protein diet [131]. Consumption of proteins with high digestibility, or a low protein diet, results in less protein reaching the colon, limiting the amount available for protein-fermenting bacteria [130]. Furthermore, changes in the gut microbiota can impact the bioavailability of dietary amino acids [104,132].

Studies carried out in mice, rats, and hamsters have shown higher microbial diversity in those fed soy protein versus animal protein $[133,134]$ and increased abundance of Bacteroidales family S24-7 in those fed soy protein versus other diets [79]. Li et al. (2017) assessed high protein, low carbohydrate diets in dogs and found decreased Bacteroidetes to Firmicutes ratio, increased Bacteroides to Prevotella ratio and increased abundance of Clostridium hiranonis, Clostridium perfringens, and Ruminococcus gnavus, the latter of which has been proposed to have beneficial effects in the human gut [135].

It has been reported that protein consumption is correlated positively with gut microbiota diversity [136]. This is based on studies carried out on healthy volunteers [137], elite athletes [125], and obese/overweight individuals [138]. The source of protein appears influential, with plant protein associated with more Bifidofacterium, Lactobacillus, Roseburia, Eubacterium rectale, and Ruminococcus bromii; and less Bacteroides and Clostridium perfringens [136,137]. Meanwhile animal protein was associated with higher levels of Bacteroides, Alistipes, Bilophila and Ruminococcus, and lower levels of Bifidobacterium [136,137]. High levels of Bacteroides have also been reported with Western diets, which are high in protein and animal fat [33], although it has been suggested that differences in fat content, rather than protein, is the major influencing factor here [139]. Significant associations have been reported between increased levels of faecal short chain fatty acids (SCFAs), Prevotella and some Firmicutes, with consumption of a Mediterranean diet $[35,140]$, which is typically lower in protein than animal-based diets, although may contain high levels of plant-source protein. Dietary fibre is an important factor in gut microbiome diversity and composition and it is important to note that most plant sources of protein are also high in fibre, whereas animal source protein are not. This is likely to be an influential factor in the findings of these studies.

The gut microbiomes of critically ill patients on average display enrichment of virulent pathogens, and loss of health-promoting microbes [141]. Protein supplementation has shown some benefits for muscle parameters in this population [142,143], but whether this effect is modulated by the gut microbiome remains to be tested. Evidently dietary protein has a significant effect on gut microbiota composition and vice versa, however more research is needed to further characterise this relationship. It is notable that almost exclusively, studies to date have focused on composition of the microbiota rather than functional capacity of the microbiome. Investigation into the differences in microbial genes involved in protein metabolism between individuals differing in anabolic response to protein could lead to the engineering of new probiotics with specific capacity to influence MPS. 


\subsection{Gut Microbiota and Anabolic Resistance}

A healthy gut microbiome plays a role in many of the physiological processes implicated in the various mechanisms proposed for the development of anabolic resistance (see Table 2 and Figure 3). These include suppression of chronic inflammation, prevention of insulin resistance, modulation of host gene expression, enhancement of antioxidant activity, and maintenance of gut barrier function [35,104].

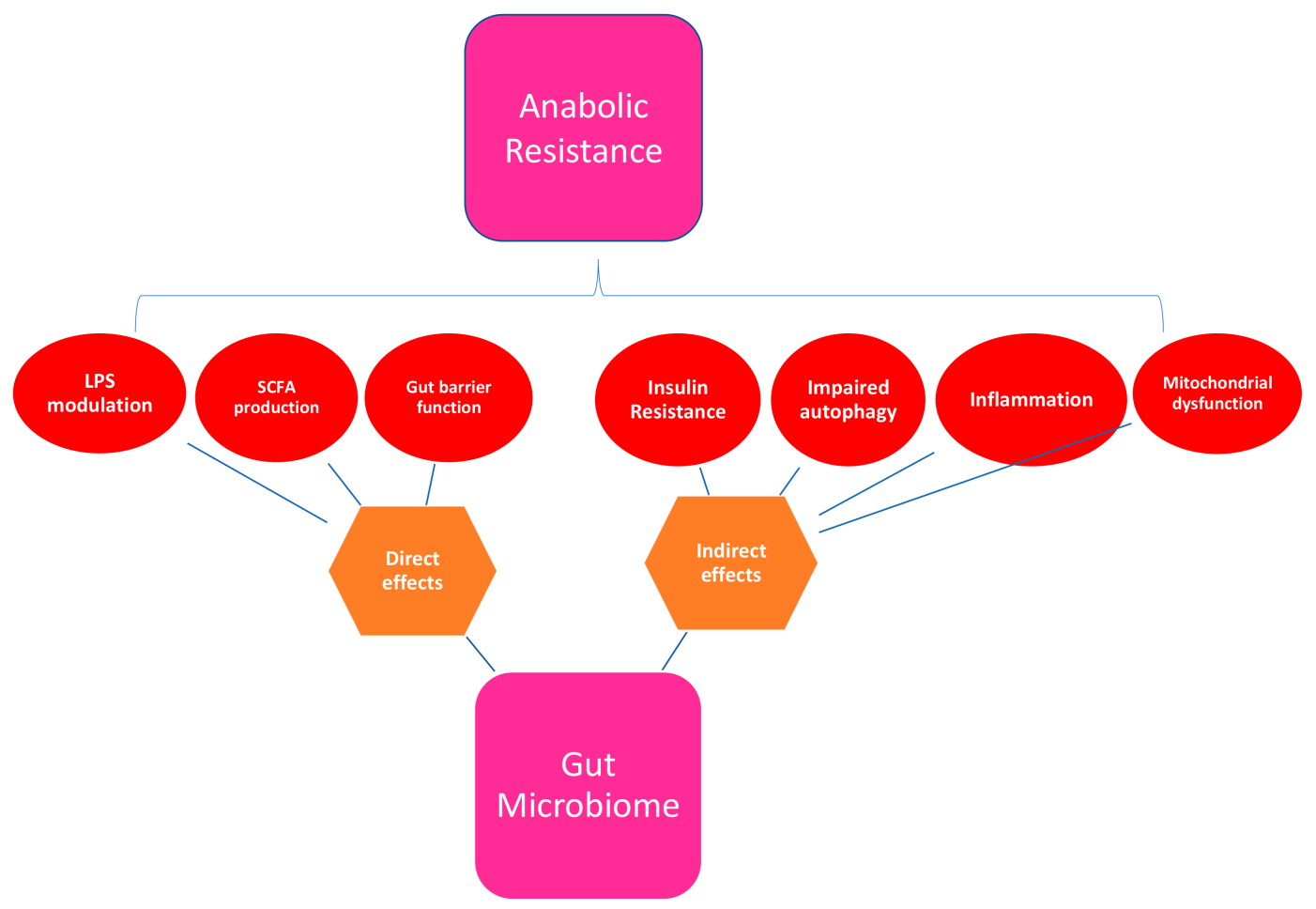

Figure 3. Mechanisms by which the gut microbiome may influence anabolic resistance. LPS: Lipopolysaccharide; SCFA: Short chain fatty acids.

Inflammation has been proposed as a contributing factor to anabolic resistance in aging, and indeed inflammaging has been suggested as a major aetiological factor in the development of sarcopenia. Biagi et al. (2010) studied age-related differences in both the gut microbiota and the inflammatory status among different stages of the whole adult life, including centenarians, and reported dysbiosis in the older population, which correlated with increased inflammatory status, as determined by peripheral blood inflammatory markers [37].

Work in animal models has shown evidence of increased intestinal permeability in association with age-associated microbial dysbiosis [36,104,144]. This can facilitate translocation of microbial byproducts into the circulation, including endotoxins, and may influence a number of the mechanisms listed in Table 2, such as protein digestion and absorption. It has been suggested that pathogenic drivers of inflammation and muscle atrophy may enter the system via this process [132]. Within humans, a randomised controlled trial of probiotic use in athletic men reported reduced zonulin in faeces, a surrogate marker of enhanced gut permeability [145], suggesting that modulation of the gut microbiota can affect the gut's barrier function.

Older adults tend to have reduced intestinal motility, which may unfavourably affect the utilisation of dietary protein by the gut [104]. Indeed it has been reported that the proteolytic potential of the gut microbiota appeared to be enhanced in older age [146], and may therefore contribute to anabolic resistance to ingested protein. There is also some evidence that probiotics may improve amino acid absorption from protein $[147,148]$, which adds weight to the suggestion that targeting the gut microbiota may ameliorate anabolic resistance in older adults. Production of SCFAs by the gut 
microbiota has been associated with anabolism itself [110] and depletion of taxa producing SCFAs may promote anabolic resistance [149]. Of note, an age-related reduction of the abundance of genes in pathways that are involved in SCFA production has been reported [146]. SCFAs are mainly produced by the fermentation of dietary fibre, so the fibre content of dietary protein sources is likely too, to influence protein metabolism.

Treatment with butyrate (a SCFA), which is associated with Bifidobacterium, was found to be protective of muscle atrophy in mice [116]. Notably, studies showing correlation between frailty and gut microbiota composition have also reported dysbiotic shifts in higher functioning older adults towards a greater abundance of butyrate-producing bacteria such as Faecalibacterium prausnitzii [95,150], which suggests these microbes may have a positive role in protection against muscle loss and frailty. Butyrate also has a role in intestinal barrier function [151], and therefore may be implicated in intestinal permeability. Notably, a randomised controlled trial of symbiotic (a combination of pre- and probiotic) use in older people noted an increase in butyrate production in those given the synbiotic [152].

Mitochondrial dysfunction and impaired autophagy have both been suggested as possible mechanisms for anabolic resistance (see Table 2). Interestingly, they have also been implicated in animal models of aging [153] and in the development of sarcopenia and cachexia [154,155]. A recent paper has postulated that dysfunctional mitochondria may represent a key link between chronic inflammation and age-related muscle loss, and that dysbiosis of the gut microbiota may be a key mediator in this gut-muscle crosstalk [104].

Evidently, there are multiple mechanisms by which the gut microbiome may influence anabolic resistance in older adults (see Figure 3), and it is likely to be a complex interaction between a number of, if not all, of these postulated processes. The hypothesis that the dysbiotic gut plays a role in the loss of skeletal muscle and response to protein is yet to be tested. If supported, the gut microbiota could represent a target for interventions aiming to overcome anabolic resistance, to maintain muscle mass and strength in older adults, with the aim of ultimately preventing the development of sarcopenia and/or frailty.

\subsection{The Metabolome}

Studies use multiple ways of estimating dietary protein intake. The validity and reliability of these dietary measures has usually been verified in younger populations and may not be relevant to older people. Indeed reduced reliability coefficients of the Food Frequency Questionnaire have been reported with increasing age [156]. In order to overcome this, researchers have sought objective estimates of dietary intakes. Protein is the major nitrogen-containing substance in the body, and therefore urinary excretion of nitrogen is used as a marker of protein loss [23,40]. Urinary [31,131] and blood urea concentration [131], and urinary HMB levels [157] have also been used with the aim of objectively verifying compliance. These methods are not without limitations, as they may not consider subtle changes with protein metabolism that occur with age, such as increased splanchnic uptake [50]. The amount of fermentation metabolites detectable in the urine depends on the digestibility of the protein [130], so this too needs to be considered. Another way to study gut microbiota composition is altered fermentation products. Promisingly, the faecal metabolome has been shown to be largely reflective of gut microbial composition [158]. Trials using ${ }^{1} \mathrm{H}$-nuclear magnetic resonance (NMR) technology have shown a shift in bacterial metabolism with different metabolite profiles according to the source of protein [131]. A growing number of studies are using ${ }^{1} \mathrm{H}-\mathrm{NMR}$ technology to assess faecal, urinary, and plasma metabolomes as measures of metabolic health (e.g., [159]). More research is needed into the use of the metabolome in the context of dietary protein intake, and the significance of metabolome changes for skeletal muscle mass and function.

\section{Discussion}

As the world's population ages, it has become imperative to gain more understanding of the aging process. Declines in muscle mass and function with age have significant associated morbidity and 
mortality, and the prevalence of both sarcopenia and frailty is increasing. The care of older people is complex, and a multitude of factors influence lower protein intake and loss of skeletal muscle with age (see Figure 1). Studies show that supplementing protein, particularly in combination with resistance exercise, is beneficial for aging muscle. However, trials have had conflicting results. Perhaps a more personalised approach is warranted? Attempting to answer this question is a large randomised controlled trial, currently being carried out, on personalised dietary recommendations as part of a multi-component intervention in the management of sarcopenia [160].

Anabolic resistance is likely to result from cumulative declines across multiple physiological systems, with effects on both MPS and MPB, a dynamic interaction of multiple factors (see Figure 2). Current thinking must not be limited to one or two mechanisms but focus on anabolic resistance as a complex and multidimensional construct. The aetiologies and mechanisms involved are not understood and may be different for each aging individual, again suggesting a potential need for personalised medicine within this population to guide future interventions. The potential role of the gut microbiota in a substantial number of postulated mechanisms for anabolic resistance warrants further investigation (Figure 3). Targeting the gut microbiota to overcome anabolic resistance holds promise in maximising responses in participants who can undertake exercise programs, but where resources and time limit such programs. Moreover, the potential ability to influence skeletal muscle function via gut microbiota in the context of those who cannot feasibly carry out vigorous exercise programs is also an attractive idea.

Few human studies have evaluated the effects of the gut microbiome on dietary protein metabolism, and the ensuing metabolome or vice versa. Studies addressing the role of the gut microbiota in skeletal muscle function are also limited in number. Animal studies have shown promise, and one human trial in older adults showed positive improvements in muscle function with prebiotic gut microbiome modulation [129]. Furthermore, in light of difficulties in accurately capturing an individual's dietary intake from questionnaire data [161], the use of the metabolome may represent an objective and reliable way of assessing compliance with dietary interventions going forward [162], and provide a functional readout for the gut microbiome.

To date there is some supporting evidence for a hypothesis that the gut microbiome may influence the health of skeletal muscle and vice versa [35,36,104], however this remains to be formally tested. In particular, processes such as muscle metabolism and inflammation may be susceptible to modulation. Research is needed to establish whether deleterious changes in the gut microbiome contribute to skeletal muscle loss in the context of acute or chronic illness, or changes detected in apparently healthy aging. The plasticity and diversity of the gut microbiome and its metabolome, represent exciting prospects to individualise the response of skeletal muscle in older adults to dietary protein.

Author Contributions: M.N.L. and C.J.S. conceived the idea for the manuscript. M.N.L. undertook the majority of the drafting of the manuscript, under the supervision of C.J.S., R.C.E.B. assisted in the drafting and critique of the work.

Funding: This research was funded by the Chronic Disease Research Foundation grant number [WT081878MA].

Acknowledgments: M.N.L. is an Academic Clinical Fellow in Geriatric Medicine, this fellowship is funded by the National Institute of Health Research (NIHR). TwinsUK is funded by the Wellcome Trust, Medical Research Council, European Union, the NIHR-funded BioResource, Clinical Research Facility and Biomedical Research Centre based at Guy's and St Thomas' NHS Foundation Trust in partnership with King's College London. C.J.S. acknowledges funding from the Chronic Disease Research Foundation (which receives funding from The Denise Coates Foundation), the Wellcome Trust (grant WT081878MA) and the Medical Research Council (grant MR/N01183X/1).

Conflicts of Interest: The authors declare no conflict of interest. 


\section{References}

1. Welch, A.A. Nutritional influences on age-related skeletal muscle loss. Proc. Nutr. Soc. 2014, 73, 16-33. [CrossRef] [PubMed]

2. Suetta, C.; Hvid, L.G.; Justesen, L.; Christensen, U.; Neergaard, K.; Simonsen, L.; Ortenblad, N.; Magnusson, S.P.; Kjaer, M.; Aagaard, P. Effects of aging on human skeletal muscle after immobilization and retraining. J. Appl. Physiol. 2009, 107, 1172-1180. [CrossRef] [PubMed]

3. Rejc, E.; Floreani, M.; Taboga, P.; Botter, A.; Toniolo, L.; Cancellara, L.; Narici, M.; Šimunič, B.; Pišot, R.; Biolo, G.; et al. Loss of maximal explosive power of lower limbs after 2 weeks of disuse and incomplete recovery after retraining in older adults. J. Physiol. 2018, 596, 647-665. [CrossRef] [PubMed]

4. Kortebein, P.; Ferrando, A.; Lombeida, J.; Wolfe, R.; Evans, W.J. Effect of 10 Days of Bed Rest on Skeletal Muscle in Healthy Older Adults. JAMA 2007, 297, 1769. [CrossRef] [PubMed]

5. Fielding, R.A.; Vellas, B.; Evans, W.J.; Bhasin, S.; Morley, J.E.; Newman, A.B.; van Kan, G.A.; Andrieu, S.; Bauer, J.; Breuille, D.; et al. Sarcopenia: An undiagnosed condition in older adults. Consensus Definition: Prevalence, Etiology, and Consequences. J. Am. Med. Dir. Assoc. 2011, 12, 249-256. [CrossRef] [PubMed]

6. Landi, F.; Calvani, R.; Tosato, M.; Martone, A.M.; Ortolani, E.; Savera, G.; D’Angelo, E.; Sisto, A.; Marzetti, E. Protein intake and muscle health in old age: From biological plausibility to clinical evidence. Nutrients 2016, 8, 295. [CrossRef] [PubMed]

7. Pilgrim, A.; Robinson, S.; Sayer, A.A.; Roberts, H. An overview of appetite decline in older people. Nurs. Older People 2015, 27, 29-35. [CrossRef] [PubMed]

8. Whitelock, E.; Ensaff, H. On Your Own: Older Adults' Food Choice and Dietary Habits. Nutrients 2018, 10. [CrossRef] [PubMed]

9. Parry, S.W.; Finch, T.; Deary, V. How should we manage fear of falling in older adults living in the community? BMJ 2013, 346, f2933. [CrossRef] [PubMed]

10. Evans, J.R.; Fletcher, A.E.; Wormald, R.P.L.; Ng, E.S.-W.; Stirling, S.; Smeeth, L.; Breeze, E.; Bulpitt, C.J.; Nunes, M.; Jones, D.; et al. Prevalence of visual impairment in people aged 75 years and older in Britain: Results from the MRC trial of assessment and management of older people in the community. Br. J. Ophthalmol. 2002, 86, 795-800. [CrossRef] [PubMed]

11. Kremer, S.; Bult, J.H.F.; Mojet, J.; Kroeze, J.H.A. Food Perception with Age and Its Relationship to Pleasantness. Chem. Senses 2007, 32, 591-602. [CrossRef] [PubMed]

12. Malagelada, J.; Bazzoli, F.; Boeckxstaens, G.; De Loose, D.; Fried, M.; Kahrilas, P.; Lindberg, G.; Maltertheiner, P.; Salis, G.; Sharma, P.; et al. World Gastroenterology Organisation Global Guidelines: Dysphagia. J. Clin. Gastroenterol. 2014, 49, 370-378. [CrossRef] [PubMed]

13. Sura, L.; Madhavan, A.; Carnaby, G.; Crary, M.A. Dysphagia in the elderly: Management and nutritional considerations. Clin. Interv. Aging 2012, 7, 287-298. [CrossRef] [PubMed]

14. Delaney, M.; McCarthy, M. Food Choice and Health across the Life Course: A Qualitative Study Examining Food Choice in Older Irish Adults. J. Food Prod. Mark. 2011, 17, 114-140. [CrossRef]

15. Age UK Later Life in the United Kingdom. 2018. Available online: https:/ / www.ageuk.org.uk/globalassets/ age-uk/documents / reports-and-publications/later_life_uk_factsheet.pdf (accessed on 2 June 2018).

16. Barnett, A.M.; Roy, N.C.; McNabb, W.C.; Cookson, A.L. The interactions between endogenous bacteria, dietary components and the mucus layer of the large bowel. Food Funct. 2012, 3, 690. [CrossRef] [PubMed]

17. Payne, R.A.; Avery, A.J.; Duerden, M.; Saunders, C.L.; Simpson, C.R.; Abel, G.A. Prevalence of polypharmacy in a Scottish primary care population. Eur. J. Clin. Pharmacol. 2014, 70, 575-581. [CrossRef] [PubMed]

18. Kamphuis, C.B.; de Bekker-Grob, E.W.; van Lenthe, F.J. Factors affecting food choices of older adults from high and low socioeconomic groups: A discrete choice experiment. Am. J. Clin. Nutr. 2015, 101, 768-774. [CrossRef] [PubMed]

19. Clegg, A.; Young, J.; Iliffe, S.; Rikkert, M.O.; Rockwood, K. Frailty in elderly people. Lancet 2013, 381, 752-762. [CrossRef]

20. Houston, D.K.; Nicklas, B.J.; Ding, J.; Harris, T.B.; Tylavsky, F.A.; Newman, A.B.; Lee, J.S.; Sahyoun, N.R.; Visser, M.; Kritchevsky, S.B. Dietary protein intake is associated with lean mass change in older, community-dwelling adults: The Health, Aging, and Body Composition (Health ABC) Study. Am. J. Clin. Nutr. 2008, 87, 150-155. [CrossRef] [PubMed] 
21. Isanejad, M.; Mursu, J.; Sirola, J.; Kröger, H.; Rikkonen, T.; Tuppurainen, M.; Erkkilä, A.T. Dietary protein intake is associated with better physical function and muscle strength among elderly women. Br. J. Nutr. 2016, 115, 1281-1291. [CrossRef] [PubMed]

22. Landi, F.; Calvani, R.; Tosato, M.; Martone, A.M.; Picca, A.; Ortolani, E.; Savera, G.; Salini, S.; Ramaschi, M.; Bernabei, R.; et al. Animal-derived protein consumption is associated with muscle mass and strength in community-dwellers: Results from the Milan EXPO Survey. J. Nutr. Health Aging 2017, 21, 1050-1056. [CrossRef] [PubMed]

23. Zhu, K.; Kerr, D.A.; Meng, X.; Devine, A.; Solah, V.; Binns, C.W.; Prince, R.L. Two-Year Whey Protein Supplementation Did Not Enhance Muscle Mass and Physical Function in Well-Nourished Healthy Older Postmenopausal Women. J. Nutr. 2015, 145, 2520-2526. [CrossRef] [PubMed]

24. Tieland, M.; Franssen, R.; Dullemeijer, C.; van Dronkelaar, C.; Kim, H.K.; Ispoglou, T.; Zhu, K.; Prince, R.L.; van Loon, L.J.C.; de Groot, L.C.P.G.M. The impact of dietary protein or amino acid supplementation on muscle mass and strength in elderly people: Individual participant data and meta-analysis of RCT's. J. Nutr. Health Aging 2017, 21, 994-1001. [CrossRef] [PubMed]

25. Beaudart, C.; Rabenda, V.; Simmons, M.; Geerinck, A.; Araujo de Carvalho, I.; Reginster, J.-Y.; Amuthavalli Thiyagarajan, J.; Bruyère, O. Effects of protein, essential amino acids, B-hydroxy B-methylbutyrate, creatine, dehydroepiandrosterone and fatty acid supplementation on muscle mass, muscle strength and physical performance in older people aged 60 years and over. A systematic review of the literature. J. Nutr. Health Aging 2017, 1-14. [CrossRef]

26. Cruz-Jentoft, A.J.; Landi, F.; Schneider, S.M.; Zúñiga, C.; Arai, H.; Boirie, Y.; Chen, L.K.; Fielding, R.A.; Martin, F.C.; Michel, J.; et al. Prevalence of and interventions for sarcopenia in ageing adults: A systematic review. Report of the International Sarcopenia Initiative (EWGSOP and IWGS). Age Ageing 2014, 43, 748-759. [CrossRef] [PubMed]

27. Cholewa, J.M.; Dardevet, D.; Lima-Soares, F.; de Araújo Pessôa, K.; Oliveira, P.H.; dos Santos Pinho, J.R.; Nicastro, H.; Xia, Z.; Cabido, C.E.T.; Zanchi, N.E. Dietary proteins and amino acids in the control of the muscle mass during immobilization and aging: Role of the MPS response. Amino Acids 2017, 49, 811-820. [CrossRef] [PubMed]

28. Deutz, N.E.P.; Bauer, J.M.; Barazzoni, R.; Biolo, G.; Boirie, Y.; Bosy-Westphal, A.; Cederholm, T.; Cruz-Jentoft, A.J.; Krznaric, Z.; Sreekumaran Nair, K.; et al. Protein intake and exercise for optimal muscle function with aging: Recommendations from the ESPEN Expert Group. Clin. Nutr. 2014, 33, 929-936. [CrossRef] [PubMed]

29. Murphy, C.H.; Saddler, N.I.; Devries, M.C.; McGlory, C.; Baker, S.K.; Phillips, S.M. Leucine supplementation enhances integrative myofibrillar protein synthesis in free-living older men consuming lower- and higher-protein diets: A parallel-group crossover study. Am. J. Clin. Nutr. 2016, 104, 1594-1606. [CrossRef] [PubMed]

30. Daly, R.; Formica, M.B.; Gianoudis, J.; Ellis, K.; O'Connell, S. Does lean red meat enhance the effetcs of exercise on muscle health and function in the elderly? Innov. Aging 2017, 1, 3-4. [CrossRef]

31. Daly, R.M.; O'Connell, S.L.; Mundell, N.L.; Grimes, C.A.; Dunstan, D.W.; Nowson, C.A. Protein-enriched diet, with the use of lean red meat, combined with progressive resistance training enhances lean tissue mass and muscle strength and reduces circulating IL-6 concentrations in elderly women: A cluster randomized controlled trial. Am. J. Clin. Nutr. 2014, 899-910. [CrossRef] [PubMed]

32. Cermak, N.M.; Res, P.T.; De Groot, L.C.; Saris, W.H.M.; Loon, L.J.C. Van Protein supplementation augments the adaptive response of skeletal muscle to resistance type exercise training a meta analysis. Am. J. Clin. Nutr. 2012, 96, 1454-1464. [CrossRef] [PubMed]

33. Wu, G.D.; Bushmanc, F.D.; Lewis, J.D. Diet, the human gut microbiota, and IBD. Anaerobe 2013, 24, 117-120. [CrossRef] [PubMed]

34. O'Keefe, S.J.D. Towards the determination of the nutritional needs of the body and its microbiome in sickness and in health. Curr. Opin. Gastroenterol. 2014, 30, 175-177. [CrossRef] [PubMed]

35. Ticinesi, A.; Lauretani, F.; Milani, C.; Nouvenne, A.; Tana, C.; Del Rio, D.; Maggio, M.; Ventura, M.; Meschi, T. Aging Gut Microbiota at the Cross-Road between Nutrition, Physical Frailty, and Sarcopenia: Is There a Gut-Muscle Axis? Nutrients 2017, 9. [CrossRef] [PubMed] 
36. Grosicki, G.J.; Fielding, R.A.; Lustgarten, M.S. Gut Microbiota Contribute to Age-Related Changes in Skeletal Muscle Size, Composition, and Function: Biological Basis for a Gut-Muscle Axis. Calcif. Tissue Int. 2018, 102, 433-442. [CrossRef] [PubMed]

37. Biagi, E.; Nylund, L.; Candela, M.; Ostan, R.; Bucci, L.; Pini, E.; Nikkïla, J.; Monti, D.; Satokari, R.; Franceschi, C.; et al. Through Ageing, and Beyond: Gut Microbiota and Inflammatory Status in Seniors and Centenarians. PLoS ONE 2010, 5, e10667. [CrossRef]

38. Ridaura, V.K.; Faith, J.J.; Rey, F.E.; Cheng, J.; Alexis, E.; Kau, A.L.; Griffin, N.W.; Lombard, V.; Henrissat, B.; Bain, J.R.; et al. Gut microbiota from twins discordant for obesity modulate metabolism in mice. Science 2013, 341, 1241214. [CrossRef] [PubMed]

39. Dillon, E.L. Nutritionally essential amino acids and metabolic signaling in aging. Amino Acids 2013, 45, 431-441. [CrossRef] [PubMed]

40. Mitchell, C.J.; Milan, A.M.; Mitchell, S.M.; Zeng, N.; Ramzan, F.; Sharma, P.; Knowles, S.O.; Roy, N.C.; Sjödin, A.; Wagner, K.H.; et al. The effects of dietary protein intake on appendicular lean mass and muscle function in elderly men: A 10-wk randomized controlled trial. Am. J. Clin. Nutr. 2017, 106, 1375-1383. [CrossRef] [PubMed]

41. Haran, P.H.; Rivas, D.A.; Fielding, R.A. Role and potential mechanisms of anabolic resistance in sarcopenia. J. Cachexia. Sarcopenia Muscle 2012, 3, 157-162. [CrossRef] [PubMed]

42. Breen, L.; Phillips, S.M. Skeletal Muscle Protein Metabolism in the Elderly: Interventions to Counteract the "Anabolic Resistance" of Ageing. Available online: http:/ /www.ncbi.nlm.nih.gov/pubmed/21975196 (accessed on 13 July 2018).

43. Stefanetti, R.J.; Zacharewicz, E.; Della Gatta, P.; Garnham, A.; Russell, A.P.; Lamon, S. Ageing Has No Effect on the Regulation of the Ubiquitin Proteasome-Related Genes and Proteins Following Resistance Exercise. Available online: http:/ / www.ncbi.nlm.nih.gov/pubmed/24550841 (accessed on 13 July 2018).

44. Moore, D.R.; Churchward-Venne, T.A.; Witard, O.; Breen, L.; Burd, N.A.; Tipton, K.D.; Phillips, S.M. Protein ingestion to stimulate myofibrillar protein synthesis requires greater relative protein intakes in healthy older versus younger men. J. Gerontol. Ser. A Biol. Sci. Med. Sci. 2015, 70, 57-62. [CrossRef] [PubMed]

45. Shad, B.J.; Thompson, J.L.; Breen, L. Does the muscle protein synthetic response to exercise and amino acid-based nutrition diminish with advancing age? A systematic review. Am. J. Physiol. Endocrinol. Metab. 2016, 311, E803-E817. [CrossRef] [PubMed]

46. Wolfe, R.R. The role of dietary protein in optimizing muscle mass, function and health outcomes in older individuals. Br. J. Nutr. 2012, 108, 88-93. [CrossRef] [PubMed]

47. Malafarina, V.; Uriz-Otano, F.; Iniesta, R.; Gil-Guerrero, L. Effectiveness of Nutritional Supplementation on Muscle Mass in Treatment of Sarcopenia in Old Age: A Systematic Review. J. Am. Med. Dir. Assoc. 2013, 14, 10-17. [CrossRef] [PubMed]

48. Dulac, M.C.; Pion, C.H.; Lemieux, F.; Boutros El Hajj, G.; Belanger, M.; Gaudreau, P.; Chevalier, S.; Morais, J.A.; Gouspillou, G.; Aubertin-Leheudre, M. Differences in muscle adaptation to a 12-week mixed power training in elderly men, depending on usual protein intake. Exp. Gerontol. 2018. [CrossRef] [PubMed]

49. Nowson, C.; O'Connell, S. Protein requirements and recommendations for older people: A review. Nutrients 2015, 7, 6874-6899. [CrossRef] [PubMed]

50. Bauer, J.; Biolo, G.; Cederholm, T.; Cesari, M.; Cruz-Jentoft, A.J.; Morley, J.E.; Phillips, S.; Sieber, C.; Stehle, P.; Teta, D.; et al. Evidence-Based Recommendations for Optimal Dietary Protein Intake in Older People: A Position Paper From the PROT-AGE Study Group. J. Am. Med. Dir. Assoc. 2013, 542-559. [CrossRef] [PubMed]

51. Churchward-Venne, T.A.; Breen, L.; Phillips, S.M. Alterations in human muscle protein metabolism with aging: Protein and exercise as countermeasures to offset sarcopenia. BioFactors 2014, 40, 199-205. [CrossRef] [PubMed]

52. Markofski, M.M.; Volpi, E. Protein metabolism in women and men: Similarities and disparities. Curr. Opin. Clin. Nutr. Metab. Care 2011, 14, 93-97. [CrossRef] [PubMed]

53. Smith, G.I.; Villareal, D.T.; Sinacore, D.R.; Shah, K.; Mittendorfer, B. Muscle Protein Synthesis Response to Exercise Training in Obese, Older Men and Women. Available online: http:/ / www.ncbi.nlm.nih.gov / pubmed/22246218 (accessed on 4 July 2018). 
54. Karastergiou, K.; Smith, S.R.; Greenberg, A.S.; Fried, S.K. Sex Differences in Human Adipose Tissues-The Biology of Pear Shape. Available online: http:/ /www.ncbi.nlm.nih.gov/pubmed/22651247 (accessed on 4 July 2018).

55. Burd, N.A.; Gorissen, S.H.; Van Loon, L.J.C. Anabolic Resistance of Muscle Protein Synthesis with Aging. Exerc. Sport Sci. Rev. 2013, 41, 169-173. [CrossRef] [PubMed]

56. Murton, A.J. Muscle protein turnover in the elderly and its potential contribution to the development of sarcopenia. Proc. Nutr. Soc. 2015, 74, 387-396. [CrossRef] [PubMed]

57. Breen, L.; Stokes, K.A.; Churchward-Venne, T.A.; Moore, D.R.; Baker, S.K.; Smith, K.; Atherton, P.J.; Phillips, S.M. Two weeks of reduced activity decreases leg lean mass and induces "anabolic resistance" of myofibrillar protein synthesis in healthy elderly. J. Clin. Endocrinol. Metab. 2013, 98, 2604-2612. [CrossRef] [PubMed]

58. Wall, B.T.; van Loon, L.J. Nutritional strategies to attenuate muscle disuse atrophy. Nutr. Rev. 2013, 71, 195-208. [CrossRef] [PubMed]

59. Biolo, G.; Ciocchi, B.; Lebenstedt, M.; Barazzoni, R.; Zanetti, M.; Platen, P.; Heer, M.; Guarnieri, G. Short-term bed rest impairs amino acid-induced protein anabolism in humans. J. Physiol. 2004, 558, 381-388. [CrossRef] [PubMed]

60. Glover, E.I.; Phillips, S.M.; Oates, B.R.; Tang, J.E.; Tarnopolsky, M.A.; Selby, A.; Smith, K.; Rennie, M.J. Immobilization induces anabolic resistance in human myofibrillar protein synthesis with low and high dose amino acid infusion. Supplementary Data. J. Physiol. 2008, 586, 6049-6061. [CrossRef] [PubMed]

61. Wall, B.T.; Snijders, T.; Senden, J.M.G.; Ottenbros, C.L.P.; Gijsen, A.P.; Verdijk, L.B.; van Loon, L.J.C. Disuse Impairs the Muscle Protein Synthetic Response to Protein Ingestion in Healthy Men. J. Clin. Endocrinol. Metab. 2013, 98, 4872-4881. [CrossRef] [PubMed]

62. Guillet, C.; Masgrau, A.; Walrand, S.; Boirie, Y. Impaired protein metabolism: Interlinks between obesity, insulin resistance and inflammation. Obes. Rev. 2012, 13, 51-57. [CrossRef] [PubMed]

63. Balage, M.; Averous, J.; Rémond, D.; Bos, C.; Pujos-Guillot, E.; Papet, I.; Mosoni, L.; Combaret, L.; Dardevet, D. Presence of low-grade inflammation impaired postprandial stimulation of muscle protein synthesis in old rats. J. Nutr. Biochem. 2010, 21, 325-331. [CrossRef] [PubMed]

64. Volpi, E.; Mittendorfer, B.; Rasmussen, B.B.; Wolfe, R.R. The response of muscle protein anabolism to combined hyperaminoacidemia and glucose-induced hyperinsulinemia is impaired in the elderly. J. Clin. Endocrinol. Metab. 2000, 85, 4481-4490. [CrossRef] [PubMed]

65. Meneilly, G.S.; Elliot, T.; Bryer-Ash, M.; Floras, J.S. Insulin-mediated increase in blood flow is impaired in the elderly. J. Clin. Endocrinol. Metab. 1995, 80, 1899-1903. [CrossRef] [PubMed]

66. Murton, A.J.; Marimuthu, K.; Mallinson, J.E.; Selby, A.L.; Smith, K.; Rennie, M.J.; Greenhaff, P.L. Obesity Appears to Be Associated With Altered Muscle Protein Synthetic and Breakdown Responses to Increased Nutrient Delivery in Older Men, but Not Reduced Muscle Mass or Contractile Function. Diabetes 2015, 64, 3160-3171. [CrossRef] [PubMed]

67. Volpato, S.; Bianchi, L.; Cherubini, A.; Landi, F.; Maggio, M.; Savino, E.; Bandinelli, S.; Ceda, G.P.; Guralnik, J.M.; Zuliani, G.; et al. Prevalence and clinical correlates of sarcopenia in community-dwelling older people: Application of the EWGSOP definition and diagnostic algorithm. J. Gerontol. A. Biol. Sci. Med. Sci. 2014, 69, 438-446. [CrossRef] [PubMed]

68. Parr, E.B.; Camera, D.M.; Areta, J.L.; Burke, L.M.; Phillips, S.M.; Hawley, J.A.; Coffey, V.G. Alcohol Ingestion Impairs Maximal Post-Exercise Rates of Myofibrillar Protein Synthesis following a Single Bout of Concurrent Training. PLoS ONE 2014, 9, e88384. [CrossRef] [PubMed]

69. Drummond, M.J.; Miyazaki, M.; Dreyer, H.C.; Pennings, B.; Dhanani, S.; Volpi, E.; Esser, K.A.; Rasmussen, B.B. Expression of growth-related genes in young and older human skeletal muscle following an acute stimulation of protein synthesis. J. Appl. Physiol. 2009, 106, 1403-1411. [CrossRef] [PubMed]

70. Tanner, R.E.; Brunker, L.B.; Agergaard, J.; Barrows, K.M.; Briggs, R.A.; Kwon, O.S.; Young, L.M.; Hopkins, P.N.; Volpi, E.; Marcus, R.L.; et al. Age-related differences in lean mass, protein synthesis and skeletal muscle markers of proteolysis after bed rest and exercise rehabilitation. J. Physiol. 2015, 593, 4259-4273. [CrossRef] [PubMed]

71. Greig, C.A.; Gray, C.; Rankin, D.; Young, A.; Mann, V.; Noble, B.; Atherton, P.J. Blunting of adaptive responses to resistance exercise training in women over 75 y. Exp. Gerontol. 2011, 46, 884-890. [CrossRef] [PubMed] 
72. Drummond, M.J.; Addison, O.; Brunker, L.; Hopkins, P.N.; McClain, D.A.; Lastayo, P.C.; Marcus, R.L. Downregulation of E3 ubiquitin ligases and mitophagy-related genes in skeletal muscle of physically inactive, frail older women: A cross-sectional comparison. J. Gerontol. Ser. A Biol. Sci. Med. Sci. 2014, 69, 1040-1048. [CrossRef] [PubMed]

73. Lecker, S.H.; Jagoe, R.T.; Gilbert, A.; Gomes, M.; Baracos, V.; Bailey, J.; Price, S.R.; Mitch, W.E.; Goldberg, A.L. Multiple types of skeletal muscle atrophy involve a common program of changes in gene expression. FASEB J. 2004, 18, 39-51. [CrossRef] [PubMed]

74. Cuthbertson, D.; Smith, K.; Babraj, J.; Leese, G.; Waddell, T.; Atherton, P.; Wackerhage, H.; Taylor, P.M.; Rennie, M.J. Anabolic signaling deficits underlie amino acid resistance of wasting, aging muscle. FASEB J. 2005, 19, 422-424. [CrossRef] [PubMed]

75. Drummond, M.J.; Dickinson, J.M.; Fry, C.S.; Walker, D.K.; Gundermann, D.M.; Reidy, P.T.; Timmerman, K.L.; Markofski, M.M.; Paddon-Jones, D.; Rasmussen, B.B.; et al. Bed rest impairs skeletal muscle amino acid transporter expression, mTORC1 signaling, and protein synthesis in response to essential amino acids in older adults. Am. J. Physiol. Endocrinol. Metab. 2012, 302, E1113-E1122. [CrossRef] [PubMed]

76. Fry, C.S.; Drummond, M.J.; Glynn, E.L.; Dickinson, J.M.; Gundermann, D.M.; Timmerman, K.L.; Walker, D.K.; Volpi, E.; Rasmussen, B.B. Skeletal muscle autophagy and protein breakdown following resistance exercise are similar in younger and older adults. J. Gerontol. A Biol. Sci. Med. Sci. 2013, 68, 599-607. [CrossRef] [PubMed]

77. Dickinson, J.M.; Fry, C.S.; Drummond, M.J.; Gundermann, D.M.; Walker, D.K.; Glynn, E.L.; Timmerman, K.L.; Dhanani, S.; Volpi, E.; Rasmussen, B.B. Mammalian target of rapamycin complex 1 activation is required for the stimulation of human skeletal muscle protein synthesis by essential amino acids. J. Nutr. 2011, 141, 856-862. [CrossRef] [PubMed]

78. Fry, C.S.; Drummond, M.J.; Glynn, E.L.; Dickinson, J.M.; Gundermann, D.M.; Timmerman, K.L.; Walker, D.K.; Dhanani, S.; Volpi, E.; Rasmussen, B.B. Aging impairs contraction-induced human skeletal muscle mTORC1 signaling and protein synthesis. Skelet. Muscle 2011, 1, 11. [CrossRef] [PubMed]

79. Kar, S.K.; Jansman, A.J.M.; Benis, N.; Ramiro-Garcia, J.; Schokker, D.; Kruijt, L.; Stolte, E.H.; Taverne-Thiele, J.J.; Smits, M.A.; Wells, J.M. Dietary protein sources differentially affect microbiota, mTOR activity and transcription of mTOR signaling pathways in the small intestine. PLOS ONE 2017, 12, e0188282. [CrossRef] [PubMed]

80. Dickinson, J.M.; Gundermann, D.M.; Walker, D.K.; Reidy, P.T.; Borack, M.S.; Drummond, M.J.; Arora, M.; Volpi, E.; Rasmussen, B.B. Leucine-enriched amino acid ingestion after resistance exercise prolongs myofibrillar protein synthesis and amino acid transporter expression in older men. J. Nutr. 2014, 144, 1694-1702. [CrossRef] [PubMed]

81. Dickinson, J.M.; Drummond, M.J.; Coben, J.R.; Volpi, E.; Rasmussen, B.B. Aging differentially affects human skeletal muscle amino acid transporter expression when essential amino acids are ingested after exercise. Clin. Nutr. 2013, 32, 273-280. [CrossRef] [PubMed]

82. Guillet, C.; Prod'homme, M.; Balage, M.; Gachon, P.; Giraudet, C.; MORIN, L.; Grizard, J.; Boirie, Y. Impaired anabolic response of muscle protein synthesis is associated with S6K1 dysregulation in elderly humans. FASEB J. 2004, 18, 1586-1587. [CrossRef] [PubMed]

83. Markofski, M.M.; Dickinson, J.M.; Drummond, M.J.; Fry, C.S.; Fujita, S.; Gundermann, D.M.; Glynn, E.L.; Jennings, K.; Paddon-Jones, D.; Reidy, P.T.; et al. Effect of age on basal muscle protein synthesis and mTORC1 signaling in a large cohort of young and older men and women. Exp. Gerontol. 2015, 65, 1-7. [CrossRef] [PubMed]

84. Welch, A.A.; Kelaiditi, E.; Jennings, A.; Steves, C.J.; Spector, T.D.; MacGregor, A. Dietary Magnesium Is Positively Associated With Skeletal Muscle Power and Indices of Muscle Mass and May Attenuate the Association Between Circulating C-Reactive Protein and Muscle Mass in Women. J. Bone Min. Res. 2016, 31, 317-325. [CrossRef] [PubMed]

85. Schaap, L.A.; Pluijm, S.M.F.; Deeg, D.J.H.; Harris, T.B.; Kritchevsky, S.B.; Newman, A.B.; Colbert, L.H.; Pahor, M.; Rubin, S.M.; Tylavsky, F.A.; et al. Higher inflammatory marker levels in older persons: Associations with 5-year change in muscle mass and muscle strength. J. Gerontol. A Biol. Sci. Med. Sci. 2009, 64, 1183-1189. [CrossRef] [PubMed] 
86. Dillon, E.L.; Casperson, S.L.; Durham, W.J.; Randolph, K.M.; Urban, R.J.; Volpi, E.; Ahmad, M.; Kinsky, M.P.; Sheffield-Moore, M. Muscle protein metabolism responds similarly to exogenous amino acids in healthy younger and older adults during NO-induced hyperemia. Am. J. Physiol. Integr. Comp. Physiol. 2011, 301, R1408-R1417. [CrossRef] [PubMed]

87. Saffrey, M.J. Aging of the mammalian gastrointestinal tract: A complex organ system. Age 2014, 36, 9603. [CrossRef] [PubMed]

88. Boirie, Y.; Gachon, P.; Beaufrère, B. Splanchnic and whole-body leucine kinetics in young and elderly men. Am. J. Clin. Nutr. 1997, 65, 489-495. [CrossRef] [PubMed]

89. Gorissen, S.H.M.; Witard, O.C. Characterising the muscle anabolic potential of dairy, meat and plant-based protein sources in older adults. Proc. Nutr. Soc. 2018, 77, 20-30. [CrossRef] [PubMed]

90. Piasecki, M.; Ireland, A.; Piasecki, J.; Stashuk, D.W.; Swiecicka, A.; Rutter, M.K.; Jones, D.A.; McPhee, J.S. Failure to expand the motor unit size to compensate for declining motor unit numbers distinguishes sarcopenic from non-sarcopenic older men. J. Physiol. 2018, 596, 1627-1637. [CrossRef] [PubMed]

91. Stephens, F.B.; Chee, C.; Wall, B.T.; Murton, A.J.; Shannon, C.E.; van Loon, L.J.C.; Tsintzas, K. Lipid-induced insulin resistance is associated with an impaired skeletal muscle protein synthetic response to amino acid ingestion in healthy young men. Diabetes 2015, 64, 1615-1620. [CrossRef] [PubMed]

92. Kilgour, A.H.M.; Gallagher, I.J.; MacLullich, A.M.J.; Andrew, R.; Gray, C.D.; Hyde, P.; Wackerhage, H.; Husi, H.; Ross, J.A.; Starr, J.M.; et al. Increased skeletal muscle 11ßHSD1 mRNA is associated with lower muscle strength in ageing. PLoS ONE 2013, 8, e84057. [CrossRef] [PubMed]

93. Liu, W.; Klose, A.; Forman, S.; Paris, N.D.; Wei-LaPierre, L.; Cortés-Lopéz, M.; Tan, A.; Flaherty, M.; Miura, P.; Dirksen, R.T.; et al. Loss of adult skeletal muscle stem cells drives age-related neuromuscular junction degeneration. Elife 2017, 6, e26464. [CrossRef] [PubMed]

94. Jeffery, I.B.; O'Toole, P.W. Diet-microbiota interactions and their implications for healthy living. Nutrients 2013, 5, 234-252. [CrossRef] [PubMed]

95. Claesson, M.J.; Jeffery, I.B.; Conde, S.; Power, S.E.; O'Connor, E.M.; Cusack, S.; Harris, H.M.B.; Coakley, M.; Lakshminarayanan, B.; O'Sullivan, O.; et al. Gut microbiota composition correlates with diet and health in the elderly. Nature 2012, 488, 178-184. [CrossRef] [PubMed]

96. Gi Langille, M.; Meehan, C.J.; Koenig, J.E.; Dhanani, A.S.; Rose, R.A.; Howlett, S.E.; Beiko, R.G. Microbial shifts in the aging mouse gut. Microbiome 2014. [CrossRef] [PubMed]

97. Rampelli, S.; Candela, M.; Turroni, S.; Biagi, E.; Pflueger, M.; Wolters, M.; Ahrens, W.; Brigidi, P. Microbiota and lifestyle interactions through the lifespan. Trends Food Sci. Technol. 2016, 57, 265-272. [CrossRef]

98. Jackson, M.A.; Jeffery, I.B.; Beaumont, M.; Bell, J.T.; Clark, A.G.; Ley, R.E.; O'Toole, P.W.; Spector, T.D.; Steves, C.J. Signatures of early frailty in the gut microbiota. Genome Med. 2016, 8, 8. [CrossRef] [PubMed]

99. Ticinesi, A.; Milani, C.; Lauretani, F.; Nouvenne, A.; Mancabelli, L.; Lugli, G.A.; Turroni, F.; Duranti, S.; Mangifesta, M.; Viappiani, A.; et al. Gut microbiota composition is associated with polypharmacy in elderly hospitalized patients. Sci. Rep. 2017, 7, 11102. [CrossRef] [PubMed]

100. Jeffery, I.B.; Lynch, D.B.; O'Toole, P.W. Composition and temporal stability of the gut microbiota in older persons. ISME J. 2016, 10, 170-182. [CrossRef] [PubMed]

101. Pérez-Cobas, A.E.; Gosalbes, M.J.; Friedrichs, A.; Knecht, H.; Artacho, A.; Eismann, K.; Otto, W.; Rojo, D.; Bargiela, R.; von Bergen, M.; et al. Gut microbiota disturbance during antibiotic therapy: A multi-omic approach. Gut 2013, 62, 1591-1601. [CrossRef] [PubMed]

102. Boirie, Y. Physiopathological mechanism of sarcopenia. J. Nutr. Health Aging 2009, 13, 717-723. [CrossRef] [PubMed]

103. Steves, C.J.; Bird, S.; Williams, F.M.; Spector, T.D. The Microbiome and Musculoskeletal Conditions of Aging: A Review of Evidence for Impact and Potential Therapeutics. J. Bone Min. Res. 2016, 31, 261-269. [CrossRef] [PubMed]

104. Picca, A.; Fanelli, F.; Calvani, R.; Mulè, G.; Pesce, V.; Sisto, A.; Pantanelli, C.; Bernabei, R.; Landi, F.; Marzetti, E. Gut Dysbiosis and Muscle Aging: Searching for Novel Targets against Sarcopenia. Mediat. Inflamm. 2018, 7026198. [CrossRef] [PubMed]

105. Quigley, E.M.M. Commentary: Synbiotics and gut microbiota in older people-A microbial guide to healthy ageing. Aliment. Pharmacol. Ther. 2013, 38, 1141-1142. [CrossRef] [PubMed] 
106. Smith, P.; Willemsen, D.; Popkes, M.L.; Metge, F.; Gandiwa, E.; Reichard, M.; Valenzano, D.R. Regulation of Life Span by the Gut Microbiota in The Short-Lived African Turquoise Killifish. Available online: https: / / www.biorxiv.org/content/ early/2017/03/27/120980 (accessed on 8 June 2018).

107. Power, S.E.; O’Toole, P.W.; Stanton, C.; Ross, R.P.; Fitzgerald, G.F. Intestinal microbiota, diet and health. Br. J. Nutr. 2014, 111, 387-402. [CrossRef] [PubMed]

108. Bäckhed, F.; Ding, H.; Wang, T.; Hooper, L.V.; Koh, G.Y.; Nagy, A.; Semenkovich, C.F.; Gordon, J.I. The gut microbiota as an environmental factor that regulates fat storage. Proc. Natl. Acad. Sci. USA 2004, 101, 15718-15723. [CrossRef] [PubMed]

109. Bäckhed, F.; Manchester, J.K.; Semenkovich, C.F.; Gordon, J.I. Mechanisms underlying the resistance to diet-induced obesity in germ-free mice. Proc. Natl. Acad. Sci. USA 2007, 104, 979-984. [CrossRef] [PubMed]

110. Den Besten, G.; Lange, K.; Havinga, R.; Van Dijk, T.H.; Gerding, A.; Van Eunen, K.; Müller, M.; Groen, A.K.; Hooiveld, G.J.; Bakker, B.M.; et al. Gut-derived short-chain fatty acids are vividly assimilated into host carbohydrates and lipids. Am. J. Physiol. Gastrointest. Liver Physiol. 2013, 305, G900-G910. [CrossRef] [PubMed]

111. Yan, H.; Diao, H.; Xiao, Y.; Li, W.; Yu, B.; He, J.; Yu, J.; Zheng, P.; Mao, X.; Luo, Y.; et al. Gut microbiota can transfer fiber characteristics and lipid metabolic profiles of skeletal muscle from pigs to germ-free mice. Sci. Rep. 2016, 6, 31786. [CrossRef] [PubMed]

112. Cani, P.D.; Possemiers, S.; Van de Wiele, T.; Guiot, Y.; Everard, A.; Rottier, O.; Geurts, L.; Naslain, D.; Neyrinck, A.; Lambert, D.M.; et al. Changes in gut microbiota control inflammation in obese mice through a mechanism involving GLP-2-driven improvement of gut permeability. Gut 2009, 58, 1091-1103. [CrossRef] [PubMed]

113. Bindels, L.B.; Beck, R.; Schakman, O.; Martin, J.C.; De Backer, F.; Sohet, F.M.; Dewulf, E.M.; Pachikian, B.D.; Neyrinck, A.M.; Thissen, J.-P.; et al. Restoring Specific Lactobacilli Levels Decreases Inflammation and Muscle Atrophy Markers in an Acute Leukemia Mouse Model. PLoS ONE 2012, 7, e37971. [CrossRef] [PubMed]

114. Chen, Y.-M.; Wei, L.; Chiu, Y.-S.; Hsu, Y.-J.; Tsai, T.-Y.; Wang, M.-F.; Huang, C.-C. Lactobacillus plantarum TWK10 Supplementation Improves Exercise Performance and Increases Muscle Mass in Mice. Nutrients 2016, 8, 205. [CrossRef] [PubMed]

115. Bindels, L.B.; Neyrinck, A.M.; Claus, S.P.; Le Roy, C.I.; Grangette, C.; Pot, B.; Martinez, I.; Walter, J.; Cani, P.D.; Delzenne, N.M. Synbiotic approach restores intestinal homeostasis and prolongs survival in leukaemic mice with cachexia. ISME J. 2016, 10, 1456-1470. [CrossRef] [PubMed]

116. Walsh, M.E.; Bhattacharya, A.; Sataranatarajan, K.; Qaisar, R.; Sloane, L.; Rahman, M.M.; Kinter, M.; Van Remmen, H. The histone deacetylase inhibitor butyrate improves metabolism and reduces muscle atrophy during aging. Aging Cell 2015, 14, 957-970. [CrossRef] [PubMed]

117. Shing, C.M.; Peake, J.M.; Lim, C.L.; Briskey, D.; Walsh, N.P.; Fortes, M.B.; Ahuja, K.D.K.; Vitetta, L. Effects of probiotics supplementation on gastrointestinal permeability, inflammation and exercise performance in the heat. Eur. J. Appl. Physiol. 2014, 114, 93-103. [CrossRef] [PubMed]

118. Salarkia, N.; Ghadamli, L.; Zaeri, F.; Sabaghian Rad, L. Effects of probiotic yogurt on performance, respiratory and digestive systems of young adult female endurance swimmers: A randomized controlled trial. Med. J. Islam. Repub. Iran 2013, 27, 141-146. [PubMed]

119. Cerdá, B.; Pérez, M.; Pérez-Santiago, J.D.; Tornero-Aguilera, J.F.; González-Soltero, R.; Larrosa, M. Gut Microbiota Modification: Another Piece in the Puzzle of the Benefits of Physical Exercise in Health? Front. Physiol. 2016, 7, 51. [CrossRef] [PubMed]

120. Clark, A.; Mach, N. The Crosstalk between the Gut Microbiota and Mitochondria during Exercise. Front. Physiol. 2017, 8, 319. [CrossRef] [PubMed]

121. Choi, J.J.; Eum, S.Y.; Rampersaud, E.; Daunert, S.; Abreu, M.T.; Toborek, M. Exercise attenuates PCB-induced changes in the mouse gut microbiome. Environ. Health Perspect. 2013, 121, 725-730. [CrossRef] [PubMed]

122. Queipo-Ortuño, M.I.; Seoane, L.M.; Murri, M.; Pardo, M.; Gomez-Zumaquero, J.M.; Cardona, F.; Casanueva, F.; Tinahones, F.J. Gut microbiota composition in male rat models under different nutritional status and physical activity and its association with serum leptin and ghrelin levels. PLoS ONE 2013, 8, e65465. [CrossRef] [PubMed] 
123. Petriz, B.A.; Castro, A.P.; Almeida, J.A.; Gomes, C.P.; Fernandes, G.R.; Kruger, R.H.; Pereira, R.W.; Franco, O.L. Exercise induction of gut microbiota modifications in obese, non-obese and hypertensive rats. BMC Genom. 2014, 15, 511. [CrossRef] [PubMed]

124. Bilski, J.; Mazur-Bialy, A.; Hubalewska-Mazgaj, M.; Brzozowski, B.; Surmiak, M.; Wojcik, D.; Magierowski, M.; Chmura, A.; Magierowska, K.; Brzozowski, T. Role of Gut-Adipose-muscle Axis in Beneficial Effect of Voluntary Exercise on Experimental Colitis in Mice Fed a Diet-Induced Obesity. Involvement of Protective Irisin and Proinflammatory Biomarkers Released from Mesenteric Fat and Colonic Mucosa. Gastroenterology 2017, 152, S828. [CrossRef]

125. Clarke, S.F.; Murphy, E.F.; O’Sullivan, O.; Lucey, A.J.; Humphreys, M.; Hogan, A.; Hayes, P.; O’Reilly, M.; Jeffery, I.B.; Wood-Martin, R.; et al. Exercise and associated dietary extremes impact on gut microbial diversity. Gut 2014, 63, 1913-1920. [CrossRef] [PubMed]

126. Oettlé, G.J. Effect of moderate exercise on bowel habit. Gut 1991, 32, 941-944. [CrossRef] [PubMed]

127. Vandeputte, D.; Falony, G.; Vieira-Silva, S.; Tito, R.Y.; Joossens, M.; Raes, J. Stool consistency is strongly associated with gut microbiota richness and composition, enterotypes and bacterial growth rates. Gut 2015. [CrossRef] [PubMed]

128. Zhu, L.; Liu, W.; Alkhouri, R.; Baker, R.D.; Bard, J.E.; Quigley, E.M.; Baker, S.S. Structural changes in the gut microbiome of constipated patients. Physiol. Genom. 2014, 46, 679-686. [CrossRef] [PubMed]

129. Buigues, C.; Fernández-Garrido, J.; Pruimboom, L.; Hoogland, A.J.; Navarro-Martínez, R.; Martínez-Martínez, M.; Verdejo, Y.; Mascarós, M.C.; Peris, C.; Cauli, O. Effect of a Prebiotic Formulation on Frailty Syndrome: A Randomized, Double-Blind Clinical Trial. Int. J. Mol. Sci. 2016, 17. [CrossRef] [PubMed]

130. Ma, N.; Tian, Y.; Wu, Y.; Ma, X. Contributions of the Interaction between Dietary Protein and Gut Microbiota to Intestinal Health. Curr. Protein Pept. Sci. 2017, 18. [CrossRef] [PubMed]

131. Beaumont, M.; Portune, K.J.; Steuer, N.; Lan, A.; Cerrudo, V.; Audebert, M.; Dumont, F.; Mancano, G.; Khodorova, N.; Andriamihaja, M.; et al. Quantity and source of dietary protein influence metabolite production by gut microbiota and rectal mucosa gene expression: A randomized, parallel, double-blind trial in overweight humans. Am. J. Clin. Nutr. 2017, 106, 1005-1019. [CrossRef] [PubMed]

132. Bindels, L.B.; Delzenne, N.M. Muscle wasting: The gut microbiota as a new therapeutic target? Int. J. Biochem. Cell Biol. 2013, 45, 2186-2190. [CrossRef] [PubMed]

133. Butteiger, D.N.; Hibberd, A.A.; Mcgraw, N.J.; Napawan, N.; Hall-porter, J.M.; Krul, E.S. Soy Protein Compared with Milk Protein in a Western Diet Increases Gut Microbial Diversity and Reduces Serum Lipids in Golden Syrian Hamsters. J. Nutr. 2016, 146, 697-705. [CrossRef] [PubMed]

134. An, C.; Kuda, T.; Yazaki, T.; Takahashi, H.; Kimura, B. Caecal fermentation, putrefaction and microbiotas in rats fed milk casein, soy protein or fish meal. Appl. Microbiol. Biotechnol. 2014, 98, 2779-2787. [CrossRef] [PubMed]

135. Li, Q.; Lauber, C.L.; Czarnecki-Maulden, G.; Pan, Y.; Hannah, S.S. Effects of the dietary protein and carbohydrate ratio on gut microbiomes in dogs of different body conditions. MBio 2017, 8, 1-14. [CrossRef] [PubMed]

136. Singh, R.K.; Chang, H.W.; Yan, D.; Lee, K.M.; Ucmak, D.; Wong, K.; Abrouk, M.; Farahnik, B.; Nakamura, M.; Zhu, T.H.; et al. Influence of diet on the gut microbiome and implications for human health. J. Transl. Med. 2017, 15, 1-17. [CrossRef] [PubMed]

137. David, L.A.; Maurice, C.F.; Carmody, R.N.; Gootenberg, D.B.; Button, J.E.; Wolfe, B.E.; Ling, A.V.; Devlin, A.S.; Varma, Y.; Fischbach, M.A.; et al. Diet rapidly and reproducibly alters the human gut microbiome. Nature 2014, 505, 559-563. [CrossRef] [PubMed]

138. Cotillard, A.; Kennedy, S.P.; Kong, L.C.; Prifti, E.; Pons, N.; Le Chatelier, E.; Almeida, M.; Quinquis, B.; Levenez, F.; Galleron, N.; et al. Dietary intervention impact on gut microbial gene richness. Nature 2013, 500, 585-588. [CrossRef] [PubMed]

139. Flint, H.J.; Duncan, S.H.; Scott, K.P.; Louis, P. Links between diet, gut microbiota composition and gut metabolism. Proc. Nutr. Soc. 2015, 74, 13-22. [CrossRef] [PubMed]

140. De Filippis, F.; Pellegrini, N.; Vannini, L.; Jeffery, I.B.; La Storia, A.; Laghi, L.; Serrazanetti, D.I.; Di Cagno, R.; Ferrocino, I.; Lazzi, C.; et al. High-level adherence to a Mediterranean diet beneficially impacts the gut microbiota and associated metabolome. Gut 2016, 65, 1812-1821. [CrossRef] [PubMed]

141. Krezalek, M.A.; Yeh, A.; Alverdy, J.C.; Morowitz, M. Influence of nutrition therapy on the intestinal microbiome. Curr. Opin. Clin. Nutr. Metab. Care 2017, 20, 131-137. [CrossRef] [PubMed] 
142. Bear, D.E.; Wandrag, L.; Merriweather, J.L.; Connolly, B.; Hart, N.; Grocott, M.P.W. The role of nutritional support in the physical and functional recovery of critically ill patients: A narrative review. Crit. Care 2017, 21. [CrossRef] [PubMed]

143. Ferrie, S.; Allman-Farinelli, M.; Daley, M.; Smith, K. Protein Requirements in the Critically Ill: A Randomized Controlled Trial Using Parenteral Nutrition. J. Parenter. Enter. Nutr. 2016, 40, 795-805. [CrossRef] [PubMed]

144. Thevaranjan, N.; Puchta, A.; Schulz, C.; Naidoo, A.; Szamosi, J.C.; Verschoor, C.P.; Loukov, D.; Schenck, L.P.; Jury, J.; Foley, K.P.; et al. Age-Associated Microbial Dysbiosis Promotes Intestinal Permeability, Systemic Inflammation, and Macrophage Dysfunction. Cell Host Microbe 2017, 21, 455-466. [CrossRef] [PubMed]

145. Lamprecht, M.; Bogner, S.; Schippinger, G.; Steinbauer, K.; Fankhauser, F.; Hallstroem, S.; Schuetz, B.; Greilberger, J.F. Probiotic supplementation affects markers of intestinal barrier, oxidation, and inflammation in trained men; a randomized, double-blinded, placebo-controlled trial. J. Int. Soc. Sports Nutr. 2012, 9, 45. [CrossRef] [PubMed]

146. Rampelli, S.; Candela, M.; Turroni, S.; Biagi, E.; Collino, S.; Franceschi, C.; O’Toole, P.W.; Brigidi, P. Functional metagenomic profiling of intestinal microbiome in extreme ageing. Aging 2013, 5, 902-912. [CrossRef] [PubMed]

147. Maathuis, A.; Keller, D.; Farmer, S. Survival and metabolic activity of the GanedenBC ${ }^{30}$ strain of Bacillus coagulans in a dynamic in vitro model of the stomach and small intestine. Benef. Microbes 2010, 1, 31-36. [CrossRef] [PubMed]

148. Jäger, R.; Purpura, M.; Farmer, S.; Cash, H.A.; Keller, D. Probiotic Bacillus coagulans GBI-30, 6086 Improves Protein Absorption and Utilization. Probiotics Antimicrob. Proteins 2017. [CrossRef] [PubMed]

149. Sonnenburg, J.L.; Bäckhed, F. Diet-microbiota interactions as moderators of human metabolism. Nature 2016, 535, 56-64. [CrossRef] [PubMed]

150. Van Tongeren, S.P.; Slaets, J.P.J.; Harmsen, H.J.M.; Welling, G.W. Fecal microbiota composition and frailty. Appl. Environ. Microbiol. 2005, 71, 6438-6442. [CrossRef] [PubMed]

151. Peng, L.; Li, Z.-R.; Green, R.S.; Holzman, I.R.; Lin, J. Butyrate enhances the intestinal barrier by facilitating tight junction assembly via activation of AMP-activated protein kinase in Caco-2 cell monolayers. J. Nutr. 2009, 139, 1619-1625. [CrossRef] [PubMed]

152. Macfarlane, S.; Cleary, S.; Bahrami, B.; Reynolds, N.; Macfarlane, G.T. Synbiotic consumption changes the metabolism and composition of the gut microbiota in older people and modifies inflammatory processes: A randomised, double-blind, placebo-controlled crossover study. Aliment. Pharmacol. Ther. 2013, 38, 804-816. [CrossRef] [PubMed]

153. Ko, F.; Abadir, P.; Marx, R.; Westbrook, R.; Cooke, C.; Yang, H.; Walston, J. Impaired mitochondrial degradation by autophagy in the skeletal muscle of the aged female interleukin 10 null mouse. Exp. Gerontol. 2016, 73, 23-27. [CrossRef] [PubMed]

154. Marzetti, E.; Calvani, R.; Lorenzi, M.; Tanganelli, F.; Picca, A.; Bossola, M.; Menghi, A.; Bernabei, R.; Landi, F. Association between myocyte quality control signaling and sarcopenia in old hip-fractured patients: Results from the Sarcopenia in HIp FracTure (SHIFT) exploratory study. Exp. Gerontol. 2016, 80, 1-5. [CrossRef] [PubMed]

155. Marzetti, E.; Lorenzi, M.; Landi, F.; Picca, A.; Rosa, F.; Tanganelli, F.; Galli, M.; Doglietto, G.B.; Pacelli, F.; Cesari, M.; et al. Altered mitochondrial quality control signaling in muscle of old gastric cancer patients with cachexia. Exp. Gerontol. 2017, 87, 92-99. [CrossRef] [PubMed]

156. Stevens, J.; Metcalf, P.A.; Dennis, B.H.; Tell, G.S.; Shimakawa, T.; Folsom, A.R. Reliability of a food frequency questionnaire by ethnicity, gender, age and education. Nutr. Res. 1996, 16, 735-745. [CrossRef]

157. Deutz, N.E.P.; Pereira, S.L.; Hays, N.P.; Oliver, J.S.; Edens, N.K.; Evans, C.M.; Wolfe, R.R. Effect of $\beta$-hydroxy- $\beta$-methylbutyrate (HMB) on lean body mass during 10 days of bed rest in older adults. Clin. Nutr. 2013, 32, 704-712. [CrossRef] [PubMed]

158. Zierer, J.; Jackson, M.A.; Kastenmüller, G.; Mangino, M.; Long, T.; Telenti, A.; Mohney, R.P.; Small, K.S.; Bell, J.T.; Steves, C.J.; et al. The fecal metabolome as a functional readout of the gut microbiome. Nat. Genet. 2018, 50, 790-795. [CrossRef] [PubMed]

159. Van de Rest, O.; Schutte, B.A.M.; Deelen, J.; Stassen, S.A.M.; van den Akker, E.B.; van Heemst, D.; Dibbets-Schneider, P.; van Dipten-van der Veen, R.A.; Kelderman, M.; Hankemeier, T.; et al. Metabolic effects of a 13-weeks lifestyle intervention in older adults: The Growing Old Together Study. Aging 2016, 8, 111-126. [CrossRef] [PubMed] 
160. Marzetti, E.; Calvani, R.; Landi, F.; Hoogendijk, E.O.; Fougère, B.; Vellas, B.; Pahor, M.; Bernabei, R.; Cesari, M. SPRINTT Consortium, on behalf of the S. Innovative Medicines Initiative: The SPRINTT Project. J. Frailty Aging 2015, 4, 207-208. [PubMed]

161. Dhurandhar, N.V.; Schoeller, D.; Brown, A.W.; Heymsfield, S.B.; Thomas, D.; Sorensen, T.I.A.; Speakman, J.R.; Jeansonne, M.; Allison, D.B. Energy Balance Measurement: When Something is Not Better than Nothing. Int. J. Obes. 2015, 39, 1109-1113. [CrossRef] [PubMed]

162. Garcia-Perez, I.; Posma, J.M.; Gibson, R.; Chambers, E.S.; Hansen, T.H.; Vestergaard, H.; Hansen, T.; Beckmann, M.; Pedersen, O.; Elliott, P.; et al. Objective assessment of dietary patterns by use of metabolic phenotyping: A randomised, controlled, crossover trial. Lancet Diabetes Endocrinol. 2017, 5, 184-195. [CrossRef]

(C) 2018 by the authors. Licensee MDPI, Basel, Switzerland. This article is an open access article distributed under the terms and conditions of the Creative Commons Attribution (CC BY) license (http:/ / creativecommons.org/licenses/by/4.0/). 